\title{
Mutations in AraR leading to constitutive of arabinolytic genes in Aspergillus niger under derepressing conditions
}

\author{
Jos Reijngoud ${ }^{1} \cdot$ Malte Deseke $^{1}$ - Elmar T. M. Halbesma ${ }^{1}$ - Ebru Alazi ${ }^{1}$ - Mark Arentshorst ${ }^{1} \cdot$ Peter J. Punt $^{1,2}$. \\ Arthur F. J. Ram ${ }^{1}$ (D)
}

Received: 2 December 2018 / Revised: 8 March 2019 / Accepted: 12 March 2019 / Published online: 8 April 2019

(C) The Author(s) 2019

\begin{abstract}
The AraR transcription factor of Aspergillus niger encodes a $\mathrm{Zn}(\mathrm{II})_{2} \mathrm{Cys}_{6}$ transcription factor required for the induction of genes encoding arabinolytic enzymes. One of the target genes of AraR is $a b f A$, encoding an arabinofuranosidase. The expression of $a b f A$ as well as other L-arabinose-induced genes in A. niger requires the presence of L-arabinose or its derivative L-arabitol as an inducer to activate AraR-dependant gene expression. In this study, mutants were isolated that express L-arabinose-induced genes independently of the presence of an inducer under derepressing conditions. To obtain these mutants, a reporter strain was constructed in a $\triangle c r e A$ background containing the L-arabinose-responsive promoter (PabfA) fused to the acetamidase ( $a m d S$ ) gene. Spores of the $\triangle c r e A$ PabfA-amdS reporter strain were UV-mutagenized and mutants were obtained by their ability to grow on acetamide without the presence of inducer. From a total of 164 mutants, 15 mutants were identified to contain transacting mutations resulting in high arabinofuranosidase activity in the medium after growth under non-inducing conditions. Sequencing of the araR gene of the 15 constitutive mutants revealed that 14 mutants carried a mutation in AraR. Some mutations were found more than once and in total nine different point mutations were identified in AraR. The $\mathrm{AraR}^{\mathrm{N} 806 \mathrm{I}}$ point mutation was reintroduced into a parental strain and confirmed that this point mutation leads to inducer-independent expression of AraR target genes. The inducer independent of L-arabinose-induced genes in the $\mathrm{AraR}^{\mathrm{N} 806 \mathrm{I}}$ mutant was found to be sensitive to carbon catabolite repression, indicating that the CreA-mediated carbon catabolite repression is dominant over the $\mathrm{AraR}^{\mathrm{N} 806 \mathrm{I}}$ mutant allele. These mutations in AraR provide new opportunities to improve arabinase production in industrial fungal strains.
\end{abstract}

Keywords Transcriptional regulation $\cdot$ Plant cell wall $\cdot$ Arabinases $\cdot$ Carbon catabolite repression $\cdot$ creA

\section{Introduction}

Aspergillus niger is a saprobic fungus which produces a large arsenal of plant cell polymer-degrading enzymes. Most noticeably, these include enzymes involved in degradation of plant storage polymers such as starch and inulin, as well as

Electronic supplementary material The online version of this article (https://doi.org/10.1007/s00253-019-09777-0) contains supplementary material, which is available to authorized users.

Arthur F. J. Ram

a.f.j.ram@biology.leidenuniv.nl

1 Present address: Molecular Microbiology and Biotechnology, Institute of Biology Leiden, Leiden University, Sylviusweg 72, 2333 BE Leiden, The Netherlands

2 Dutch DNA Biotech, Hugo R Kruytgebouw 4-Noord, Padualaan 8, 3584 CH Utrecht, The Netherlands plant cell wall polymers such as cellulose, hemicellulose, and pectin (Pel et al. 2007; de Vries et al. 2017). D-Xylose and Larabinose are the most abundant pentoses in the plant cell wall. L-Arabinose is found in both hemicellulose (as arabinoxylan) and pectin (as arabinogalactan and arabinan) (McNeil et al. 1984). Filamentous fungi, including A. niger, produce a number of extracellular arabinases, including $\alpha$-Larabinofuranosidases (ABFs) and endo-arabinases (ABNs), to degrade L-arabinose-containing plant cell wall polymers (de Vries and Visser 2001). Following uptake of L-arabinose, its intracellular catabolism involves the pentose catabolic pathway which consists of a five-step metabolic route resulting in the formation of D-xylulose 5-phosphate, which is further metabolised in the pentose phosphate pathway (Khosravi et al. 2015). Several ABFs, ABNs, and L-arabinose-specific catabolic pathway genes, including the $\mathrm{L}$-arabinose reductase (LarA), L-arabitol dehydrogenase (LadA), and L-xylulose reductase (LxrA), are coordinately expressed (Flipphi et al. 
1994; de Groot et al. 2003; Battaglia et al. 2014). The last two catabolic steps in L-arabinose catabolism connect with Dxylose catabolism and include xylitol dehydrogenase (XdhA) and D-xylulose kinase (XkiA) to form D-xylulose 5-phosphate (de Groot et al. 2007). Efficient extracellular degradation of L-arabinose-containing polymeric substrates and subsequent catabolism requires a coordinated expression of the genes encoding these enzymes.

In $A$. niger, the coordinated expression of genes encoding the extracellular enzymes (ABFs and ABNs) and intracellular enzymes (LarA, LadA, LxrA, XdhA, and XkiA) in response to the presence of L-arabinose requires the $\mathrm{Zn}(\mathrm{II})_{2} \mathrm{Cys}_{6}$ transcription factor AraR (Battaglia et al. 2011, 2014). The Larabinose-responsive transcription factor AraR shows a strong sequence similarity to the $\mathrm{D}$-xylose-responsive $\mathrm{Zn}(\mathrm{II})_{2} \mathrm{Cys}_{6}$ transcription factor $\mathrm{X} \ln \mathrm{R}$ and evolutionary analysis suggests that AraR is derived from XlnR after gene duplication (Battaglia et al. 2011). Analysis of the growth phenotypes of single knockout mutants of $\operatorname{araR}$ and $x \ln R$ and the double knockout mutant on different substrates suggests partially overlapping roles for AraR and XlnR (Battaglia et al. 2011). Expression of the last two genes in the pentose catabolic pathway ( $x d h A$ and $x k i A$ ) as well as genes in the pentose phosphate pathway are not only induced on L-arabinose via AraR, but also induced on D-xylose via the D-xylose-responsive transcription factor XlnR (Battaglia et al. 2011). The two positive regulators of the pentose metabolism (XlnR and AraR) both have specific target genes, but some genes can also be under the control of both transcription factors (Kowalczyk et al. 2015; Gruben et al. 2017). Detailed comparison of the involvement of AraR and XlnR in the induction of pentose catabolic genes in A. oryzae has recently shown that all pentose catabolic pathway genes are under the control of both AraR and $\mathrm{X} \operatorname{lnR}$, except larA which is under the control of only AraR (Ishikawa et al. 2018). DNA-binding studies revealed that $\mathrm{X} \ln \mathrm{R}$ and AraR bind to similar, but not identical DNA sequences. XlnR prefers CGGNTAAW, while AraR prefers CGGDTAAW (Ishikawa et al. 2018).

The AraR transcription factor of A. niger is an 832 amino acid long protein and conserved domains include the binuclear cluster DNA-binding domain ( $\mathrm{Zn}(\mathrm{II})_{2} \mathrm{Cys}_{6}$ ) (aa 32-73) and a domain indicated as the fungal-specific transcription factor domain (also known as middle homology region) (aa 496736) (Battaglia et al. 2011). While the DNA-binding function of the $\mathrm{Zn}(\mathrm{II})_{2} \mathrm{Cys}_{6}$ domain is well established, the function of the conserved middle homology region is not clear. The mechanism by which AraR is activated in response to the presence of an inducer is also unknown. Since the accumulation of intracellular L-arabitol results in higher production of arabinolytic enzymes, L-arabitol is regarded as the inducer to activate AraR (van der Veen et al. 1993). L-Arabinose- or L-arabitol-induced gene expression and production of extracellular enzymes (arabinofuranosidases (AbfA, AbfB), endo- arabinase $(\mathrm{AbnA})$ ) and intracellular enzymes (L-arabinose reductase, L-arabitol dehydrogenase, L-xylulose reductase, and xylitol dehydrogenase) have been shown to be strongly repressed by D-glucose in a CreA-dependent manner (van der Veen et al. 1994; Flipphi et al. 1994).

The filamentous fungus $A$. niger is the main producer of arabinan-degrading enzymes in industry. The enzymes are used in several industrial applications including improvement of wine flavours, juice clarification, pulp treatment, and plant biomass degradation (Numan and Bhosle 2006; Shallom and Shoham 2003). The production of arabinan-degrading enzymes is tightly controlled and requires the presence of inducing sugars or polyols like L-arabinose or L-arabitol and the absence of repressing sugars like D-glucose. The requirement of specific inducers and the sensitivity to carbon catabolite repression limits the choice of feedstock and the use of cheap feedstocks for arabinase production.

In this study, we have isolated mutants with constitutive production of arabinases that do not require the presence of $\mathrm{L}$-arabinose or L-arabitol as inducers. Mutants were found to have specific amino acid mutations in the AraR transcriptional activator resulting in a constitutively active form of the transcription factor, bypassing the inducer requirement. Detailed analysis of one of the AraR constitutive mutants ( $\mathrm{AraR}^{\mathrm{N} 806 \mathrm{I}}$ ) revealed that the constitutive production of arabinases is still sensitive to carbon catabolite repression.

\section{Material and methods}

\section{Strains and growth conditions}

The A. niger strains used in this study are listed in Table 1. Strains were grown on either solidified ( $2 \%$ agar) or liquid minimal medium (MM) or complete medium (CM). MM contains $7 \mathrm{mM} \mathrm{KCl}, 8 \mathrm{mM} \mathrm{KH}{ }_{2} \mathrm{PO}_{4}, 70 \mathrm{mM} \mathrm{NaNO}{ }_{3}, 2 \mathrm{mM}$ $\mathrm{MgSO}_{4}$, and spore trace element solution, $\mathrm{pH} 5.5$ (Arentshorst et al. 2012). The carbon source of interest was added at a final concentration of $1 \%$. If L-arabinose was the carbon source, $0.05 \%$ of D-glucose was added to promote germination of the spores. For CM, $0.1 \%$ casamino acids and $0.5 \%$ yeast extract were added to $\mathrm{MM}$ and $1 \% \mathrm{D}$ glucose was added as a carbon source. MM-agar medium containing $10 \mathrm{mM}$ acetamide as the sole nitrogen source and $50 \mathrm{mM}$ D-glucose as carbon source were made as described previously (Arentshorst et al. 2012). For spore propagations, spores were streaked on CM-agar plates with a cotton stick and incubated at $30{ }^{\circ} \mathrm{C}$ for 3 to 5 days. The spores were isolated by adding 10 to $15 \mathrm{ml}$ of $0.9 \% \mathrm{NaCl}$ solution and scrubbed with a cotton stick. This spore suspension was taken out of the Petri dish, filtered through sterile miracloth tissue, and the number of spores was counted with a TC20 $0^{\mathrm{TM}}$ automated cell counter (Bio-Rad, Veenendaal, the Netherlands). 
Table 1 Strains used in this study

\begin{tabular}{|c|c|c|}
\hline Strain & Genotype & Reference \\
\hline N402 & $\operatorname{csp} A$ & ATCC® 64974TM; Bos et al. 1988 \\
\hline AB4.1 & pyr $G$ derivative of $\mathrm{N} 402$ & Van Hartingsveldt et al. 1987 \\
\hline $\mathrm{JN} 11.2$ & PabfA-amdS-pyrG* in AB4.1 & Niu et al. 2015 \\
\hline JN16.1 & creA:: hyg $B$ in $\mathrm{JN} 11.2$ & Niu et al. 2015 \\
\hline MA323.1 & ku70::amdS $\triangle$ nicB $\triangle p y r G$ & Niu et al. 2016 \\
\hline JR12.3 & $\operatorname{araR}^{w t}-$ pyr $G^{* *}$ in $\mathrm{AB} 4.1$ & This study \\
\hline JR13.9 & $\operatorname{araR}^{N 806 I}-p y r G^{* *}$ in $\mathrm{AB} 4.1$ & This study \\
\hline JR13.2 & $\begin{array}{l}\operatorname{araR}^{N 806 I} \text {-pyr } G^{* *} \text { in } \mathrm{AB} 4.1+\text { multiple } \\
\quad \text { copies of } \operatorname{araR}^{N 806 I} \text { randomly integrated }\end{array}$ & This study \\
\hline JN16.1 U\#7 & UV mutated JN16.1 & This study \\
\hline EH1.2 & araR::nicB in MA323.1 & This study \\
\hline $\mathrm{EH} 2.1$ & $\operatorname{araR}^{W T}-$ pyr $G^{* *}$ in EH1.2 & This study \\
\hline EH3.1 & $\operatorname{araR}^{N 806 I}-p y r G^{* *}$ in EH1.2 & This study \\
\hline JR16.2 & creA::hygB in $\mathrm{EH} 2.1$ & This study \\
\hline JR17.2 & creA $:$ hyg $B$ in $\mathrm{EH} 3.1$ & This study \\
\hline
\end{tabular}

The spores were stored in $0.9 \% \mathrm{NaCl}$ at $4{ }^{\circ} \mathrm{C}$. Five litres of bioreactor cultivation (New Brunswick Scientific, Nijmegen, the Netherlands) was performed as previously described using $0.75 \%$ D-fructose as carbon source (Niu et al. 2017).

To analyse the growth phenotypes of the strains, $5 \mu \mathrm{l}$ of spore suspension at a concentration of $1 \times 10^{5}$ spores $/ \mathrm{ml}$ was point-inoculated in the middle of an agar plate containing MM and the nitrogen and carbon sources to be assayed. The plates were incubated at $30^{\circ} \mathrm{C}$ for 4 days. For shaken liquid cultures, flasks with $50 \mathrm{ml} \mathrm{MM}$ containing the carbon source of interest were inoculated with the spore stock solution to reach a final spore concentration of $1 \times 10^{6}$ spores $/ \mathrm{ml}$. The flasks were incubated at $30^{\circ} \mathrm{C}, 250 \mathrm{rpm}$ for $36 \mathrm{~h}$ in the Innova ${ }^{\circledR} 44$ incubator (New Brunswick Scientific, Nijmegen, the Netherlands). The mycelia were separated from the growth medium by filtration and immediately frozen in liquid nitrogen. The growth medium, referred to as supernatant of the culture, was collected in a $15-\mathrm{ml}$ tube, $5 \times 1 \mathrm{ml}$ aliquots were taken, and both tube and aliquots were immediately frozen in liquid nitrogen as well. These samples were stored together with the mycelia at $-80{ }^{\circ} \mathrm{C}$ for long-term storage.

The UV-mutagenesis experiments were performed as described previously (Damveld et al. 2008) using JN16.1 (PafbA-amdS $\Delta c r e A$ ) (Niu et al. 2015) as a starting strain. Surviving spores $(70 \%)$ were plated out on MM-agar containing acetamide as sole nitrogen source and $50 \mathrm{mM}$ D-glucose as a carbon source. On each plate, about $2.5 \times 10^{5}$ spores $\left(50 \mu \mathrm{l}\right.$ of a $5 \times 10^{6}$ spores $\left./ \mathrm{ml}\right)$ were plated out. In total, 40 plates were prepared and incubated at $30{ }^{\circ} \mathrm{C}$ for 7 days. As the survival rate was about $70 \%$, about $7 \times 10^{6}$ spores were screened for growth on acetamide plates indicating constitutive expression of $a b f A$. In total, 160 mutants were obtained. In addition, spontaneous mutants were selected by plating out non-UV-treated spores at MM-acetamide/D-glucose medium. On four plates, this yielded to four mutants. All mutants were purified twice on MM-agar plates with acetamide/D-glucose and resulted in the isolation of in total 164 mutants.

\section{Plasmid and strain construction}

Transformations were carried out as described previously (Arentshorst et al. 2012). AraR was knocked out using the split marker approach (Arentshorst et al. 2015a) in which the open reading frame of araR is replaced by the nicB gene of A. nidulans in MA323.1 $\left(\Delta k u 70\right.$, nic $\left.B^{-}, p y r G^{-}\right)$. The nicB gene encodes a nicotinate mononucleotide pyrophosphorylase and can be used as an auxotrophic marker as the nicB mutant can be supplemented with nicotinamide to grow (Niu et al. 2016). Primers for constructing gene deletion fragments and diagnostic PCRs are listed in Supplemental Table S1. Proper deletion of araR in the resulting strain (EH1.2) was confirmed by diagnostic PCR and Southern blot (Supplemental Fig. S1). Subsequently, EH1.2 and AB4.1 were used to integrate an araR allele (wild type or N806I) at the $p y r G$ locus.

The $a r a R^{W T}$ and $\operatorname{araR}^{N 806 I}$ alleles including the $1-\mathrm{kb}$ flanks were PCR amplified using primers with a NotI site and cloned in pJET (Supplemental Table S1). The araR fragments were isolated from the vectors with NotI and ligated in NotIdigested $p y r G^{* *}$ targeting vector pMA334 (Arentshorst et al. 2015b) resulting in pMA334-araR ${ }^{\mathrm{WT}}$ and pMA334$\operatorname{araR}^{806}$. After verification by restriction analysis and sequencing, pMA334-araR ${ }^{\mathrm{WT}}$ and pMA334-araR ${ }^{806}$ were AscI digested to obtain linear fragments for transformation of AB4.1 and EH1.2 using the auxotrophic pyrG marker as selection marker. Proper integration of pMA334-araR ${ }^{\mathrm{WT}}$ and pMA334-araR ${ }^{806}$ at the $p y r G$ locus in EH1.2 was confirmed by Southern blot analysis (Supplemental Fig. S2). The creA gene was deleted in EH2.1 ( $\triangle$ araR $\operatorname{araR}^{W T}$ ) and EH3.1 $\left(\triangle \operatorname{araR} \operatorname{araR}^{N 806 I}\right)$ using split marker fragments with hygromycin resistance gene as a selection marker using primers listed in Supplemental Table S1. The diagnostic PCRs to confirm deletion of creA are given in Supplemental Fig. S3. Proper integration of pMA334-araR ${ }^{\mathrm{WT}}$ and pMA334$\operatorname{araR}^{806}$ at the pyrG locus in $\mathrm{AB} 4.1$ was confirmed by Southern blot analysis (Supplemental Fig. S4). 


\section{Enzyme activity assays}

Arabinofuranosidase activity in the supernatant of the liquid cultures was detected with 4-nitrophenyl $\alpha$-L-arabinofuranoside (Sigma-Aldrich, Steinheim, Germany) essentially as described by Tefsen et al. (2012).

For the screening of the 164 mutants, spores were picked from a plate with a sterile toothpick and transferred to a sterile 96-well plate filled with $200 \mu \mathrm{l}$ of MM with $1 \% \mathrm{D}$-glucose. Plates were incubated for $36 \mathrm{~h}$ at $30^{\circ} \mathrm{C}$. From each microtitre well, 2.5 and $7.5 \mu \mathrm{l}$ of cell-free growth medium were transferred to a fresh microtitre plate and measured for arabinofuranosidase activity. Arabinofuranosidase activity was measured by mixing supernatant with $44 \mu \mathrm{l} 0.1 \mathrm{M}$ sodium acetate buffer $(\mathrm{pH} 4.5)$ and $6 \mu$ of $5 \mathrm{mM} 4$-nitrophenyl $\alpha$-L-arabinofuranoside in a flat-bottom well of a 96-well plate (Sarstedt, Etten-Leur, the Netherlands). The final volume in each well was adjusted to $60 \mu \mathrm{l}$ with water. The plate was incubated for $30 \mathrm{~min}$ at $37^{\circ} \mathrm{C}$ and $240 \mu \mathrm{l} 0.25 \mathrm{M}$ sodium hydroxide was added to each well to stop the reaction. The absorbance was measured at a wavelength of $405 \mathrm{~nm}$ with the EnSpire ${ }^{\circledR}$ Multimode Plate Reader (Perkin Elmer, Rotterdam, the Netherlands). Selected strains showing arabinofuranosidase activity in the microtitre plate were also grown in shake flask cultures in $50 \mathrm{ml} \mathrm{MM}$ containing $1 \% \mathrm{D}$ glucose and incubated for $36 \mathrm{~h}$ at $30^{\circ} \mathrm{C}$ at $250 \mathrm{rpm}$. Again, cellfree medium $(2.5,5.0,7.5$, or $10.0 \mu \mathrm{l})$ was measured for arabinofuranosidase activity as described above. Control strains (N402; wild type) or JN11.2 (PabfB-amdS) were also grown in L-arabinose medium to measure arabinofuranosidase activity under inducing conditions.

\section{General molecular procedures}

The PCR amplification of the araR gene and its flanking regions for the sequencing experiments and that of the probes for the Southern and Northern blots was performed by using the Phire Hot Start II polymerase (Thermo Scientific, Breda, the Netherlands) according to instructions of the manufacturer using the Prime Thermal Cycler (Techne, (VWR) Amsterdam, the Netherlands) PCR machine. DNA isolation from the fungal mycelia frozen in liquid nitrogen was done according to the procedure described by Arentshorst et al. (2012) via a phenolchloroform-isoamyl alcohol extraction. DNA extraction from agarose gels was performed using the GeneJETTM gel extraction kit from Fermentas Life Sciences (Amsterdam, the Netherlands) according to the manufacturer's instructions. DNA concentrations were measured spectrophotometrically with the Thermo Scientific Nano Drop 2000 Spectrophotometer (Thermo Scientific, Breda, the Netherlands) at a wavelength of $260 \mathrm{~nm}$. RNA extraction and Northern blot analysis were performed as described earlier (Alazi et al. 2016). Primers for the amplification of the probes are listed in Supplemental Table S1.

\section{Sequencing of $\operatorname{araR}$ and sequence analysis}

Genomic DNA of selected constitutive mutants and the parental strain was isolated and the araR open reading frame and $1-\mathrm{kb}$ flanking regions weres PCR amplified using primers AraRP1 and AraRP2 (Supplemental Table S1). The PCR product $(4.5 \mathrm{~kb}$ ) was purified from gel and sequenced at Macrogen Europe, Amsterdam, Netherlands. Sequence analysis was performed with the software programs Serial Cloner 2.6.1 (http://serialbasics.free. fr/Serial_Cloner.html) and DNAMAN Version 4.0 (https:// lynnon.com/). The alignment of AraR and XlnR comparison was done using tools available at UniProt (www.uniprot.org).

\section{Results}

\section{In vivo reporter strains to analyse induction and carbon catabolite repression mechanisms of the L-arabinose-induced arabinofuranosidase A}

We previously constructed a PabfA-amdS reporter strain (JN11.2) and showed that expression of amdS from the arabinofuranosidase $\mathrm{A}(a b f A)$ promoter is specifically induced by L-arabinose allowing the reporter strain to grow on Larabinose and acetamide as the carbon and nitrogen source, respectively (Niu et al. 2015). As shown in Fig. 1a, L-arabitol and arabinan also induced $a b f A$ expression. Other carbon sources such as D-glucose, D-fructose, D-sorbitol, Dgalacturonic acid, and D-xylose did not result in growth of the reporter strain on acetamide, indicating that these carbon sources do not induce expression of the amdS gene from the abfA promoter (Niu et al. 2015; Fig. 1a, upper row).

In this study, we also tested whether disruption of the carbon catabolite repressor ( $c r e A)$ in the JN11.2 background affected the expression of $a b f A$ and consequently the growth on acetamide. As shown in Fig. 1a, lower row, strain JN16.1 ( $\Delta$ creA.:hygB PabfA-amdS) grew on L-arabinose, L-arabitol, and arabinan, but also on D-xylose, xylitol, and xylan, and to a lesser extent on D-galacturonic acid (GA), indicating that D-xylose and possibly GA induce $a b f A$ expression under derepressing conditions. The PabfA-amdS reporter strain in the $\Delta c r e A$ background did not grow on D-glucose, D-fructose, or D-sorbitol indicating that derepression via deletion of $c r e A$ is not sufficient to drive amdS expression from the abfA promoter to sustain growth. As expected and as shown earlier (Niu et al. 2015), both the wild-type and $\Delta c r e A$ mutants without the reporter constructs do not grow on acetamide plates on any carbon source (Fig. 1b).

Arabinofuranosidases, including $a b f A$, have been shown to be under carbon catabolite repression control (van der Veen et al. 1993; de Ruijter et al. 1997). To examine the effect of carbon catabolite repression, spores of the PabfA-amdS reporter strain were inoculated on MM-acetamide plates containing Larabinose as an inducer and increasing concentrations of D- 
a

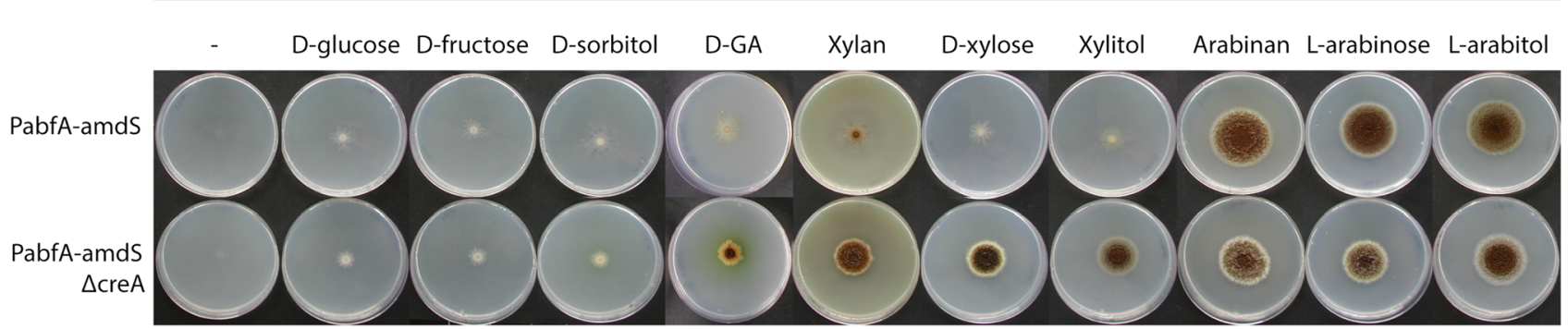

b

$\mathrm{MM}+10 \mathrm{mM}$ acetamide $+50 \mathrm{mM}$ arabinose

+ D-glucose

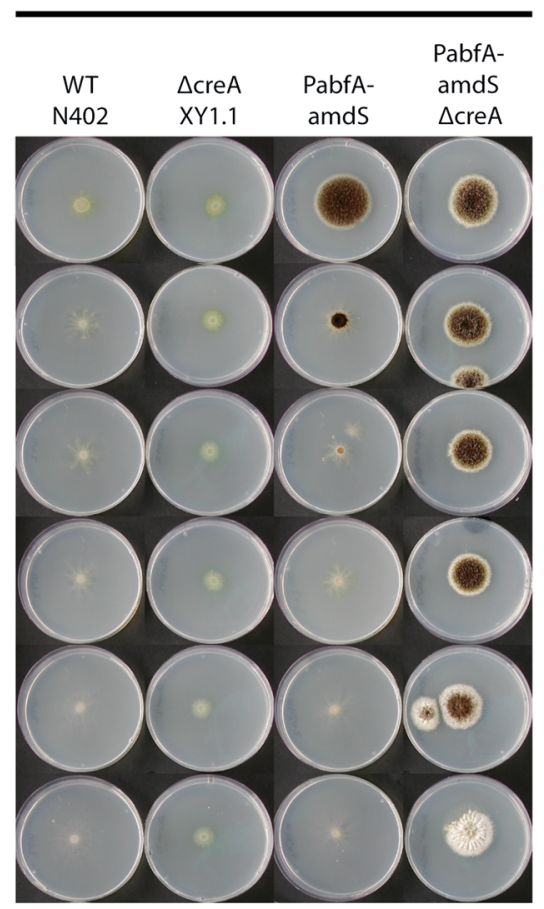

Fig. 1 Growth analysis of A. niger PabfA-amdS reporter strains. a Induction of the PabfA-amdS reporter strains in a wild-type creA background (JN11.2) or in a $\Delta c r e A$ background (JN16.1) is analysed by growing on $\mathrm{MM}$ with $10 \mathrm{mM}$ acetamide with $50 \mathrm{mM}$ monosaccharide or $1 \%$ polysaccharide. b Repression of the reporter strains is analysed by growing on $\mathrm{MM}$ with $10 \mathrm{mM}$ acetamide with $50 \mathrm{mM}$ L-arabinose as
+ D-fructose

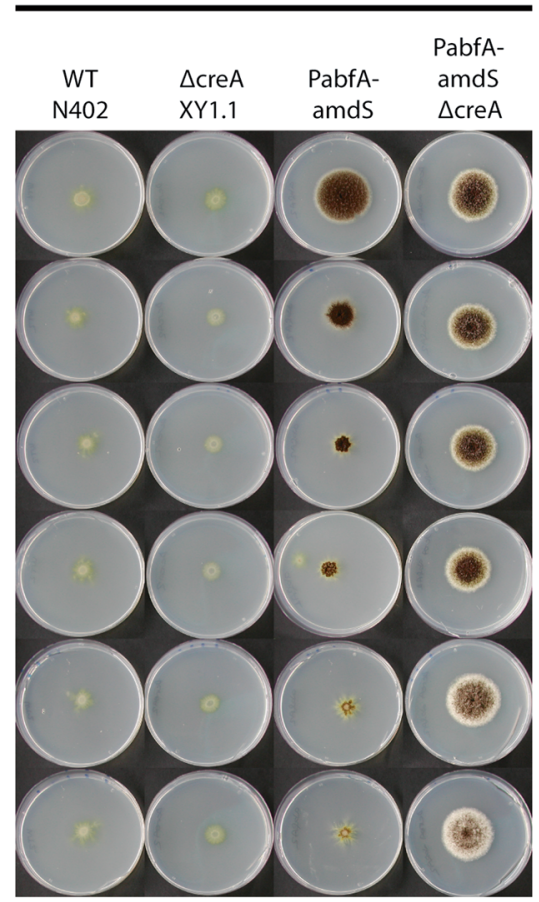

inducer and different concentrations of the repressing carbon sources, such as D-glucose, D-fructose, and D-sorbitol. A wild-type strain (N402) and a creA deletion strain (XY1.1) which do not contain the Aspergillus nidulans amdS gene are used as negative controls. Strains were grown for 7 days at $30{ }^{\circ} \mathrm{C}$

\section{Isolation and sequence analysis of trans-acting mutants with constitutive expression of L-arabinose-induced genes}

To select for mutants with constitutive expression of $a b f A$, JN16.1 (PabfA-amdS $\Delta c r e A:: h y g B$ ) was UV-mutagenized and surviving spores (70\% survival rate) were plated out on MMagar plates with acetamide as the sole nitrogen source and Dglucose as a carbon source. In addition, four plates with non-UVreporter strain (Fig. 1b). 
treated spores were plated to select for spontaneous mutants. In total, 160 UV mutants and four spontaneous mutants were isolated after two rounds of purification on MM-acetamide/D-glucose plates.

To identify trans-acting mutants, 20 mutants were tested for arabinofuranosidase activity by growing them in shake flask cultures with MM-D-glucose medium and analysing the supernatant for arabinofuranosidase activity. Of these 20 mutants, four displayed higher arabinofuranosidase activity compared to the parental strain. Next, the remaining 144 mutants were grown in MM-glucose medium in microtitre plates to assay total arabinofuranosidase activity. From the 144 mutants, 13 of them showed an arabinofuranosidase activity at least twofold above background resulting in a total of 17 mutants producing arabinofuranosidases under non-inducing conditions (data not shown). All mutants with higher arabinofuranosidase activity were obtained after UV mutagenesis.

To determine whether mutations in $\operatorname{araR}$ were responsible for the constitutive expression of arabinolytic genes, the araR locus of the 17 mutants was PCR amplified and sequenced. In 16 out the 17 mutants, mutations in araR were found, indicating that the AraR transcription factor itself is the major target to obtain mutants constitutively expressing arabinases (Fig. 2). Two mutations $\left(\mathrm{AraR}^{\mathrm{I763F}}\right.$ and $\mathrm{AraR}^{\mathrm{D} 504 \mathrm{~N}}$ ) were found in five and two mutants, respectively. In addition to these two mutations, seven additional mutations in $\operatorname{araR}$ were identified, all leading to an amino acid change in the protein sequence. Mutant \#57 contained two mutations (I502M and D504N). Since constitutive mutant \#151 contained only the D504N mutation, we cannot conclude whether the I502M mutation by itself also leads to constitutive expression, and therefore, the I502M mutation was not considered to be leading to constitutive phenotype. In mutant \#3, no mutations were found in the $\operatorname{araR}$ gene, nor in the $x \ln R$ gene, and no mutations were found in the $1-\mathrm{kb}$ upstream regions of both araR and $x \ln R$. To compare arabinofuranosidase activities of the parental strain (JN16.1) and 17 constitutive mutants, strains were grown in duplicate under comparable conditions in shake flask cultures in MM-glucose for $36 \mathrm{~h}$ and the arabinofuranosidase activity was determined. Comparison of the arabinofuranosidase activities detected in the growth medium among the mutants identified the $\operatorname{AraR}^{\mathrm{I} 763 \mathrm{~F}}$ (mutants \#46, \#85, \#104, \#116, and \#128) and the AraR ${ }^{\text {N806I }}$ (mutant \#7) as the AraR variants with the strongest constitutive expression (Fig. 2).

\section{The AraR $^{\mathrm{N8061}}$ mutation is responsible for the constitutive production of arabinofuranosidases}

Because of its high arabinofuranosidase activity under noninducing conditions, mutant \#7 carrying the AraR ${ }^{\mathrm{N} 806 \mathrm{I}}$ mutation was selected for further analysis. To confirm that besides
$\mathrm{AraR}^{\mathrm{N} 806 \mathrm{I}}$ no additional UV-introduced mutations were responsible for the constitutive phenotype, araR was knocked out (EH1.2) and subsequently complemented by $\operatorname{araR} R^{W T}$ $(\mathrm{EH} 2.1)$ or the constitutive $\operatorname{araR}^{N 806 I}$ allele (EH3.1) at the pyr $G$ locus by targeted integration. Proper deletion of araR in EH1.2 was confirmed by phenotypic growth analysis on MM-L-arabinose agar plates (data not shown) and Southern blot analysis (Supplemental Fig. S1) and integration of either the wild-type $\operatorname{araR}$ allele or $\operatorname{araR}{ }^{N 806 I}$ allele at the $\operatorname{pyr} G$ locus was confirmed by Southern blot (Supplemental Fig. S3). Subsequently, the creA gene was deleted in both strains resulting in strains JR 16.2 and JR17.2 respectively (Supplemental Fig. S4). The reconstituted mutant strain JR17.2 showed constitutive arabinofuranosidase activity under non-inducing condition comparable to the original mutant, indicating that the $\mathrm{AraR}^{\mathrm{N} 806 \mathrm{I}}$ mutation is solely responsible for the constitutive phenotype (Fig. 2). Strain JR16.2 did not show arabinofuranosidase activity under non-inducing conditions as expected.

\section{The AraR $^{\mathrm{N8061}}$ mutation behaves as a semi-dominant mutation and is overruled by CreA-mediated repression during exponential growth}

To determine whether the $\mathrm{AraR}^{\mathrm{N} 806 \mathrm{I}}$ mutation is dominant over the wild-type AraR, strain JR13.9 was constructed which, in addition to the araR wild-type gene at the endogenous locus, contains the $\mathrm{AraR}^{\mathrm{N} 806 \mathrm{I}}$ allele, expressed from its own promoter at the $\operatorname{pyr} G$ locus. As a control strain, JR12.3 was constructed which contains an extra copy of the wild-type araR gene at the $\operatorname{pyr} G$ locus. Correct and single-copy integration of $a r a R^{W T}$ and $\operatorname{araR}^{N 806 I}$ was confirmed by Southern blot analysis and sequencing (Supplemental Fig. S2). In the Southern blot analysis of transformants, also a multicopy (mc) transformant (JR13.2) containing at least two copies of the $\mathrm{AraR}^{\mathrm{N} 806 \mathrm{I}}$ allele (mc-araR ${ }^{N 806 \mathrm{I}}$ ) was identified and included in the analysis. As a control, we used strain EH3.1, which only contains the $\operatorname{araR}{ }^{N 806 I}$ allele at the $\operatorname{pyr} G$ locus and is lacking the endogenous araR gene.

Because these four strains contain the wild-type creA gene, they were cultivated using D-fructose as a non-inducing, lessrepressing carbon source. Maximum biomass accumulation and growth rate of the four strains were similar indicating that there were no growth differences between the strains (Table 2). Time points representing exponential phase ( $70 \%$ and $90 \%$ of maximal biomass accumulation) and time point representing stationary phase $(20 \mathrm{~h}$ and $70 \mathrm{~h}$ after D-fructose depletion) were selected to determine arabinofuranosidase activity as described in the "Material and methods" section. No arabinofuranosidase activity was detected in any of the four strains during exponential growth, indicating constitutive expression is prevented during exponential growth possibly by carbon catabolite repressing mechanism even on D-fructose. 


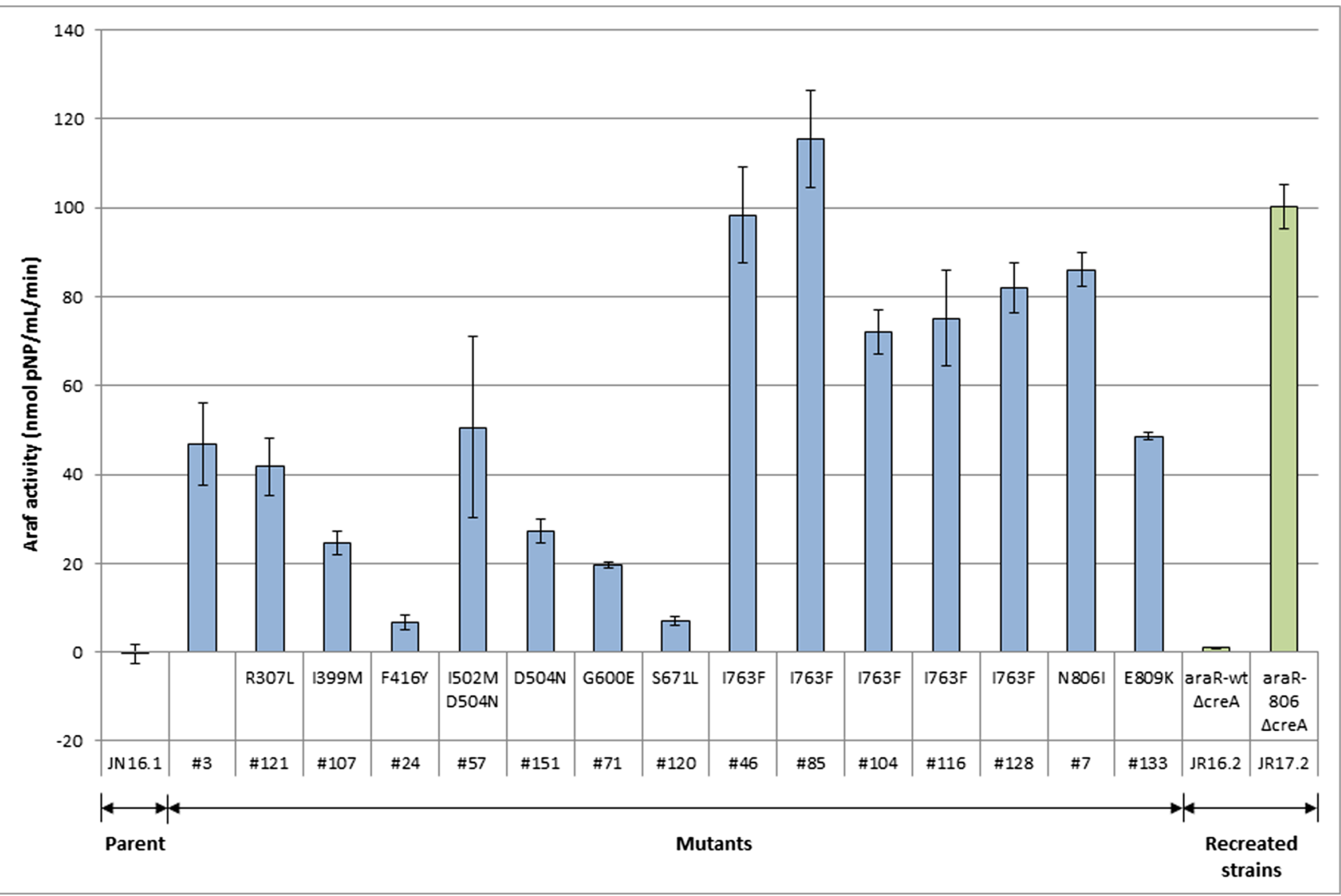

Fig. 2 Arabinofuranosidase activity of the A. niger parental strain containing the PabfA-amdS reporter construct (JN16.1), the mutants derived from JN16.1 after UV mutagenesis (bars in blue), and the reconstructed $\triangle c r e A \operatorname{araR}^{W T}$ (JR16.2) and the reconstructed $\Delta c r e A$

Increased arabinofuranosidase activity was detected in strains carrying the mutant $\mathrm{AraR}^{\mathrm{N} 806 \mathrm{I}}$ allele during stationary phase (Table 2). The highest activity during stationary phase was found for the strain carrying multiple copies of $\mathrm{AraR}^{\mathrm{N} 806 \mathrm{I}}$ allele (JR13.2) or in the strain containing only the $\mathrm{AraR}^{\mathrm{N} 806 \mathrm{I}}$ allele (EH3.1). The strain containing both the wild-type araR gene and the mutant form (JR13.9) showed intermediate arabinofuranosidase activity $20 \mathrm{~h}$ after carbon depletion. The results suggest that the $\mathrm{AraR}^{\mathrm{N} 806 \mathrm{I}}$ allele is semi-dominant over the wild-type AraR allele.

To show that CreA-mediated repression is responsible for the repression of arabinofuranosidase activity during exponential growth in the strains expressing the $\mathrm{AraR}^{\mathrm{N} 806 \mathrm{I}}$ allele, the original $\mathrm{AraR}^{\mathrm{N} 806 \mathrm{I}}$ mutant $\left(\mathrm{JN} 16.1 \# 7\right.$, $\operatorname{araR}^{\mathrm{N806I}} \Delta$ creA) was cultured in bioreactor on D-fructose. The growth rate of this mutant, as well as the parental strain (JN16.1), was lower as compared to the wild-type due to creA deletion (Table 2). Arabinofuranosidase activity in $\mathrm{JN} 16.1 \# 7$ was already detected during exponential phase, indicating that CreA represses arabinofuranosidase production during exponential growth in the strains carrying the $\mathrm{AraR}^{\mathrm{N} 806 \mathrm{I}}$ mutant allele even when grown on D-fructose.
$\operatorname{araR}^{N 806 I}$ (JR17.2) strains (bars in green). All trains were grown in $50 \mathrm{ml}$ MM-D-glucose medium supplemented with $0.0003 \%$ yeast extract for $36 \mathrm{~h} 30{ }^{\circ} \mathrm{C}$ at $250 \mathrm{rpm}$. Error bars represent the variation between biological duplicates

To examine which L-arabinose-induced genes are expressed in the various mutants during exponential and stationary phase, the expression of several AraR target genes $a b f A, a b f B, a b f C, a b n A$, and $l a d A$ were monitored at time points representing exponential phase (90\% of maximal biomass accumulation) and time point representing stationary phase (20 h after D-fructose depletion) (Fig. 3).

The expression of arabinofuranosidases $a b f A, a b f B$, and $a b f C$ correlated well with the arabinofuranosidase activity measurements. No expression of $a b f A, a b f B$, or $a b f C$ was detected during exponential growth in any of the strains that contain a functional $c r e A$ gene. Also $a b n A$ and $l a d A$ were not expressed during exponential growth. Strains containing the $\mathrm{AraR}^{\mathrm{N} 806 \mathrm{I}}$ allele (JR13.2 and EH3.1) showed expression of the AraR target genes abnA, $a b f B$, and $a b f C$ only during stationary phase (Fig. 3). This suggests that expression of these genes by the constitutive $\mathrm{AraR}^{\mathrm{N} 806 \mathrm{I}}$ occurs only under derepressing conditions which fully supports the arabinofuranosidase activity measurements. Combining the constitutive $\mathrm{AraR}^{\mathrm{N} 806 \mathrm{I}}$ allele together with the deletion of $\mathrm{creA}$ (JN16.1\#7) resulted in expression of all the AraR target genes investigated both during exponential and stationary phases (Fig. 3). Expression levels of ladA and abfA show similar 


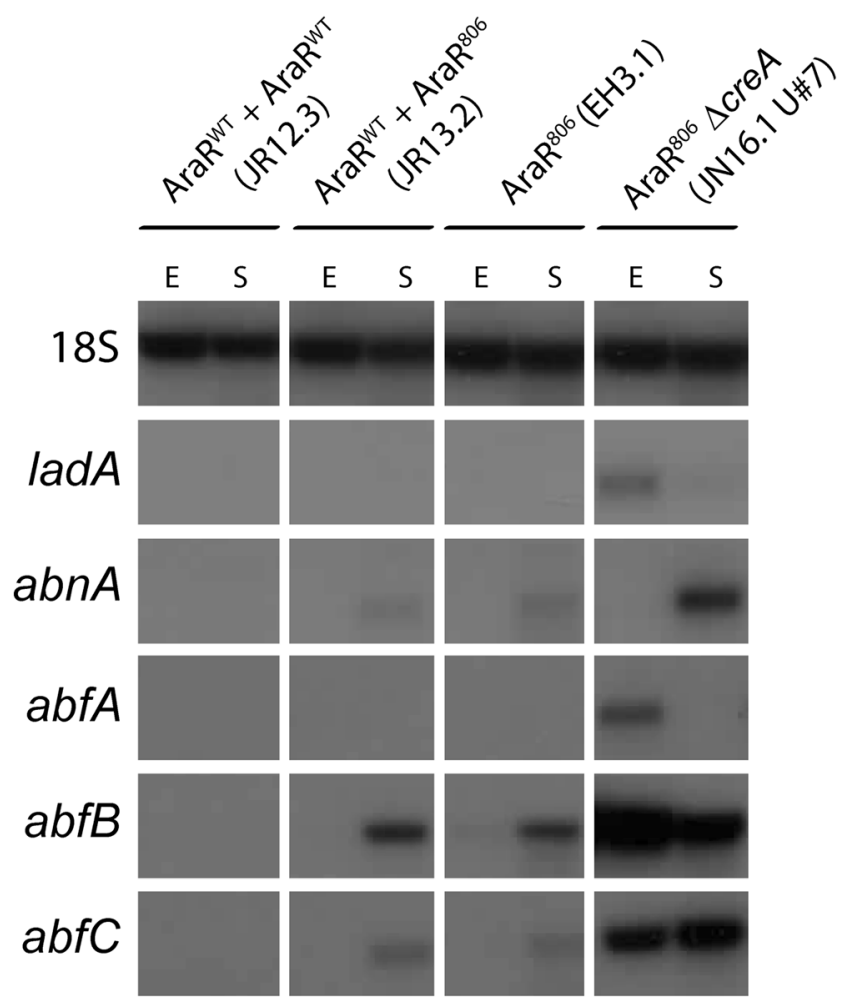

Fig. 3 Expression analysis of L-arabinose-responsive genes in submerged batch cultivation at the end of exponential phase (E) and at stationary phase (S). Strains were grown in $\mathrm{pH} 3.0$ controlled 5-1 bioreactors containing minimal medium with $0.75 \%$ D-fructose as carbon source as described in the "Material and methods." Throughout cultivation, mycelium samples were taken from the cultures and stored at $-80^{\circ} \mathrm{C}$. Samples corresponding with a biomass yield of $90 \%$ of the maximum biomass reached, or samples corresponding with the time point $20 \mathrm{~h}$ after fructose depletion, representing exponential (E) or stationary (S) phases respectively were used for RNA extraction and subsequent Northern blot analysis. Probes used include ladA (L-arabitol dehydrogenase; An01g10920), $a b n A$ (endo-1,5-alpha-arabinanase; An09g01190), and the arabinofuranosidases encoded by abfA (An01g00330), $a b f B$ (An15g02300), and $a b f C$ (An08g01710). 18S RNA probe was used as loading control

patterns in that they are moderately expressed during exponential growth in the $\operatorname{araR}^{N 806 I} \Delta \mathrm{creA}$ mutant and low during starvation. Expression levels of $a b f B$ and $a b f C$ are relatively high both during exponential phase and stationary phase in the $\operatorname{araR}^{N 806 I}$ $\triangle c r e A$ mutant, and abnA is only expressed in the $\operatorname{araR}^{N 806 I}$ $\triangle c r e A$ mutant during stationary phase. This complex pattern of regulation suggests that the expression of different genes that are part of the AraR regulon are also affected by other factors, such as CreA.

\section{Discussion}

The expression of genes encoding arabinolytic enzymes is tightly controlled to ensure that enzyme production only occurs in the presence of arabinan or its derivatives like Larabinose or L-arabitol. In Eurotiomycetes, the expression of genes encoding arabinolytic enzymes is controlled by the $\mathrm{Zn}(\mathrm{II})_{2} \mathrm{Cys}_{6}$ transcriptional activator AraR (Battaglia et al. 2011, 2014; Gruben et al. 2017). Arabinolytic enzymes are not only subjected to induction by an inducer, they are also repression control via the CreA-mediated carbon catabolite control (Fig. 1b; van der Veen et al. 1993, 1994; Flipphi et al. 1994). Using the power of a positive selection strategy, we were able to identify several mutations in the AraR transcriptional regulator that lead to constitutive expression of AraR-controlled genes. The screen for mutants was performed in a $\Delta c r e A$ background to uncouple the activation and repression mechanisms. Subsequent analysis of the inducerindependent $\mathrm{AraR}^{\mathrm{N} 806 \mathrm{I}}$ mutant revealed that the inducerindependent expression was still sensitive to CreA-mediated repression. Additional attempts to isolate inducer-independent mutants in a non-creA background were not successful (Reijngoud and Ram), indicating that in our screen, is it difficult to obtain mutants that bypass the repression of CreA.

All mutations that were found in AraR are missense mutations. No frameshift or non-sense mutations leading to truncated proteins were identified. This indirectly implies there is probably no repressor protein involved in the regulation of Larabinose-induced genes that upon loss of function results in a constitutive expression of these genes as has been found before for the regulation of galacturonic-induced genes (Niu et al. 2017). If a repressor protein would be involved, it is reasonable to assume that repressor mutants would be picked up at high frequency, as loss of function mutations in the repressor are likely to occur more frequently compared to gain of function mutations in AraR. Interestingly, we identified one constitutive mutant which did not have a mutation in AraR or $\mathrm{X} \operatorname{lnR}$ and this could represent another factor involved in controlling gene expression. Molecular genetic analysis of this mutant by genome sequencing is currently performed, but outside the scope of this study.

AraR shows significant sequence similarities to its paralog $\mathrm{X} \ln \mathrm{R}$ which controls the expression of genes encoding xylanolytic enzymes (Battaglia et al. 2011). In Aspergillus species, it has been shown that AraR and XlnR have overlapping functions (Battaglia et al. 2011, 2014; Ishikawa et al. 2018) and it has recently been shown that XlnR and AraR of A. oryzae bind to similar DNA-binding sequences in their target genes (Ishikawa et al. 2018). Transcriptomic and DNA-binding studies in A. niger and A. oryzae have shown that some genes are specifically induced via AraR, others by $\mathrm{X} \operatorname{lnR}$, and again others are induced by both $\mathrm{X} \operatorname{lnR}$ and AraR (Gruben et al. 2017; Ishikawa et al. 2018).

The $a b f A$ gene has been reported to be specifically induced by arabinan, L-arabinose, and L-arabitol (Flipphi et al. 1994; Kowalczyk et al. 2017; Gruben et al. 2017) which was also confirmed using our reporter strain (Fig. 1a, upper row). However, when creA was deleted in the PabfA-amdS reporter strain, the expression of $a b f A$ was also induced by xylan, 
Table 2 Growth characteristics and arabinofuranosidase activities of A. niger strains in $\mathrm{pH}$-controlled bioreactors

\begin{tabular}{|c|c|c|c|c|c|c|c|}
\hline \multirow[t]{2}{*}{ Strain } & \multirow[t]{2}{*}{ Genotype } & \multirow{2}{*}{$\begin{array}{l}\text { Maximum } \\
\text { biomass } \\
(\mathrm{g} / \mathrm{kg})\end{array}$} & \multirow{2}{*}{$\begin{array}{l}\mu \max \\
\left(\mathrm{h}^{-1}\right)\end{array}$} & \multicolumn{4}{|c|}{ Arabinofuranosidase activity* (nmol PNP/ml/min) } \\
\hline & & & & $\begin{array}{l}70 \% \\
\text { biomass }\end{array}$ & $\begin{array}{l}90 \% \\
\text { biomass }\end{array}$ & $\begin{array}{l}20 \mathrm{~h} \text { after } \\
\mathrm{D} \text {-fructose } \\
\text { depletion }\end{array}$ & $\begin{array}{l}70 \mathrm{~h} \text { after } \\
\mathrm{D} \text {-fructose } \\
\text { depletion }\end{array}$ \\
\hline JR12.3 & $\operatorname{araR}^{w t}+\operatorname{araR}^{w t}\left(p y r G^{* *}\right)$ & $4.29 \pm 0.01$ & $0.21 \pm 0.00$ & $<0.1$ & $<0.1$ & $10.9 \pm 0.7$ & $11.9 \pm 0.1$ \\
\hline JR13.9 & $\operatorname{araR}^{w t}+\operatorname{araR}^{N 806 I}\left(\operatorname{pyr} G^{* *}\right)$ & $4.34 \pm 0.03$ & $0.21 \pm 0.01$ & $<0.1$ & $<0.1$ & $66.7 \pm 1.4$ & $103.1 \pm 3.4$ \\
\hline JR13.2 & $\operatorname{araR}^{w t}+\operatorname{araR}^{N 806 I}\left(\operatorname{pyrG}^{* *}\right)+\operatorname{mc} \operatorname{araR}^{N 806 I}$ & $4.39 \pm 0.01$ & $0.22 \pm 0.00$ & $<0.1$ & $<0.1$ & $322.3 \pm 5.6$ & Not determined \\
\hline EH3.1 & $\triangle \operatorname{araR} \operatorname{araR}^{N 806 I}\left(\right.$ pyrG $\left.^{* *}\right)$ & $4.40 \pm 0.02$ & $0.20 \pm 0.01$ & $<0.1$ & $<0.1$ & $182.6 \pm 3.3$ & $255.7 \pm 7.7$ \\
\hline JN16.1 & $\operatorname{araR}^{w t} \Delta$ cre $A: \because h y g B$ & $4.35 \pm 0.03$ & $0.15 \pm 0.02$ & $<0.1$ & $<0.1$ & $4.2 \pm 0.2$ & $6.7 \pm 0.3$ \\
\hline JN16.1 U7 & $\operatorname{araR}^{N 806 I} \Delta$ creA::hygB & $4.60 \pm 0.02$ & $0.16 \pm 0.00$ & $46.8 \pm 2.5$ & $58.61 \pm 2.0$ & $219.1 \pm 11.4$ & $288.8 \pm 1.2$ \\
\hline
\end{tabular}

*Total arabinofuranosidase activity when grown in submerged 51 batch cultivation with $0.75 \%$ D-fructose and $0.0003 \%$ yeast extract. Maximum biomass and time point of carbon deletion are determined using offline biomass measurements at the corresponding time points. Standard variation between the biological duplicates are given

D-xylose, and xylitol (Fig. 1a, lower row). This observation suggests that the activated $\mathrm{X} \operatorname{lnR}$ transcription factor can also induce expression of primary AraR target genes, but only when CreA is absent. It suggests competition for binding sites of the different transcription factors and that the absence of CreA might affect the binding affinity of XlnR to the abfA promoter resulting in higher expression of abfA on D-xylose. Alternatively, $X \ln R$ levels might be increased in the $\Delta$ creA strain and the higher abundance of $X \ln R$ might allow binding even when the binding affinity is not very high. The abfA gene contains two putative $\mathrm{X} \ln \mathrm{R} / \mathrm{AraR}$ binding sites at -383 and 94 relative to the start codon. The binding site at position 383 (CGGCTAAA) matches the binding site predicted to have preferred binding of XlnR while the binding site at position 94 (CGGTTAAT) is predicted to bind both $\mathrm{X} \operatorname{lnR}$ and AraR (Ishikawa et al. 2018). The 1000-bp promoter region of abfA contains 14 putative CreA binding sites (SYGGRG), one of which at position -97 which overlaps with the putative $\mathrm{X} \operatorname{lnR} /$ AraR binding site. It should be noted that the $\mathrm{X} \ln \mathrm{R} / \mathrm{AraR}$ or XlnR-specific binding sites are based on studies in A. oryzae (Ishikawa et al. 2018) and a similar sequence specificity has not been shown for $A$. niger.

Our results also indicate possible competition of inactive and active AraR for DNA binding, because of the observed semidominant effect when expressing constitutively active AraR in a wild-type AraR background. This observation suggests that under non-inducing conditions, inactive AraR might bind the AraR binding site in the promoter region and compete with the activated form of AraR (AraR ${ }^{\mathrm{N} 806 \mathrm{I}}$ ). Kowalczyk et al. (2015) described an interesting observation that genes encoding arabinolytic enzymes are higher expressed in response to L-arabinose in a $\Delta x \ln R$ strain. As $\mathrm{X} \operatorname{lnR}$ and AraR have very similar binding sites (Ishikawa et al. 2018), this result can be interpreted such that also inactive XlnR binds to the same binding site and competes with

Table 3 Conservation of mutated amino acids in constitutive AraR variants of A. niger (Anig) in AraR and XlnR of A. niger, Aspergillus nidulans (Anid), Aspergillus fumigatus (Afum), and Aspergillus oryzae (Aory) and Xyr1 of T. reesei

\begin{tabular}{|c|c|c|c|c|c|c|c|c|c|}
\hline $\begin{array}{l}\text { Position } \\
\text { amino acid } \\
\text { mutated }\end{array}$ & $\begin{array}{l}\text { Anig AraR } \\
\text { (A2QJX5) }\end{array}$ & $\begin{array}{l}\text { Afum AraR } \\
\text { (OXN19303) }\end{array}$ & $\begin{array}{l}\text { Anid AraR } \\
\text { (Q5BGE2) }\end{array}$ & $\begin{array}{l}\text { Aory AraR } \\
\text { (XP_023090294) }\end{array}$ & $\begin{array}{l}\text { Anig XlnR } \\
(\mathrm{CAK} 42534)\end{array}$ & $\begin{array}{l}\text { Afum XlnR } \\
\text { (B0XUL1) }\end{array}$ & $\begin{array}{l}\text { Anid XlnR } \\
(\mathrm{CAC} 81360)\end{array}$ & $\begin{array}{l}\text { Aory XlnR } \\
\text { (Q2UD93) }\end{array}$ & $\begin{array}{l}\text { T. reesei Xyr1 } \\
\text { (AAO33577) }\end{array}$ \\
\hline $\mathrm{R} 307 \mathrm{~L}$ & $\mathbf{R}$ & $\mathbf{R}$ & $\mathbf{R}$ & $\mathbf{R}$ & $\mathrm{D}$ & $\mathrm{D}$ & $\mathrm{E}$ & $\mathrm{D}$ & E \\
\hline I399M & I & I & I & I & I & V & $\mathrm{V}$ & I & V \\
\hline F416Y & $\mathbf{F}$ & $\mathbf{F}$ & $\mathbf{F}$ & $\mathbf{F}$ & W & W & W & W & W \\
\hline D504N & $D$ & $D$ & $D$ & $D$ & $D$ & $D$ & $D$ & $D$ & $D$ \\
\hline G600E & $G$ & $G$ & $G$ & $G$ & $G$ & $G$ & $G$ & $G$ & $G$ \\
\hline S671 L & $\mathrm{S}$ & A & $\mathrm{S}$ & $\mathrm{S}$ & A & A & A & A & A \\
\hline $\mathrm{I} 763 \mathrm{~F}$ & I & I & I & I & $\mathrm{V}$ & V & $\mathrm{V}$ & $\mathrm{V}$ & V \\
\hline N806I & $\mathbf{N}$ & $\mathbf{N}$ & $\mathbf{N}$ & $\mathbf{N}$ & $\mathrm{D}$ & $\mathrm{D}$ & $\mathrm{D}$ & $\mathrm{D}$ & $\mathrm{D}$ \\
\hline E809K & $E$ & $E$ & $E$ & $E$ & $E$ & $E$ & $E$ & $E$ & $E$ \\
\hline
\end{tabular}

Amino acid residues in italics are conserved in both AraR and XlnR, and amino acids in bold only in AraR. Accession numbers of the proteins are given within brackets below the gene name 
active AraR, explaining the observation that deletion of $X \ln R$ results in higher expression of arabinases.

In both A. niger and in Trichoderma reesei, specific point mutations in XlnR and Xyr1 have been described that lead to constitutive production and expression of xylanases. The two mutations are the $\mathrm{X} \ln \mathrm{R}^{\mathrm{V} 756 \mathrm{~F}}$ mutation in A. niger and the $\mathrm{Xyr}^{\mathrm{A}}{ }^{\mathrm{A} 24 \mathrm{~V}}$ mutation in T. reesei (Hasper et al. 2004; Derntl et al. 2013). In protein sequence alignment of $X \ln R$ and $X y r 1$, these two mutations are only three amino acids apart from each other (Supplemental Fig. S1). The C-terminal domain of XlnR/Xyr1 including these mutations has been suggested to be an activator domain (Hasper et al. 2004). Mutations in AraR leading to constitutive expression were not limited to a specific domain or well-conserved region in AraR. The alleles leading to the highest AraF activity (mutation at position 756 or 806) were found in the C-terminal part of the protein, indicating that this domain might serve as the AraR activation domain, similar as has been suggested for $X \ln R$.

ClustalW alignment of $\mathrm{X} \operatorname{lnR} / \mathrm{Xyr} 1$ and AraR protein sequences from A. niger, A. nidulans, A. fumigatus, and A. oryzae and Xyrl of T. reesei was performed to analyse whether the mutated amino acids in A. niger AraR were conserved among AraR or XlnR orthologs. From the nine amino acid changes in AraR that lead to constitutive expression, eight amino acids were fully conserved among AraR orthologs. Only the serine at position 675 in A. niger was not conserved in A. fumigatus (Table 3; Supplemental Fig. S5). Mutations resulting in amino acid changes at positions 504, 600, and 809 in AraR protein of A. niger were conserved in both AraR and $\mathrm{X} \operatorname{lnR} / \mathrm{Xyr} 1$. The valine at position 756 in $\mathrm{X} \operatorname{lnR}$ of $A$. niger that upon change to phenylalanine leads to constitutive activation of xylanases (Hasper et al. 2004) is conserved among Aspergilli and T. reesei $\mathrm{XlnR}$ orthologs, but not in AraR homologs. The alanine at position 824 in $T$. reesei that upon change to valine leads to constitutive activation in T. reesei Xyr1 is conserved among all $\mathrm{X} \operatorname{lnR}$ and AraR homologs (Supplemental Fig. S1). In a very recent paper, Gao et al. (2019) showed that overexpression of the homologous alanine to valine mutation in AraR of Penicillium oxalicum (AraR ${ }^{\mathrm{A} 731 \mathrm{~V}}$ ) results in constitutive $\alpha$-Larabinofuranosidase activity under carbon starvation conditions also in this species). However, our results show that also mutations in several other positions in the AraR protein can result in (partial) constitutively. It will therefore be of interest to examine whether these additional mutations can be introduced in AraR or $\mathrm{X} \operatorname{lnR}$ other species to increase arabinolytic and/or xylanolytic enzyme production. The newly identified amino acid changes leading to inducer-independent expression presented in this study also open the possibility to combine individual mutations to examine whether these mutations have additive or possible synergistic effects on enzyme production.

Little is known about the mechanism by which AraR is activated. Earlier studies have shown that intracellular L-arabitol is the inducer to activate the expression of genes encoding arabinolytic enzymes, because when the intracellular concentration of L-arabitol is high, for example, in a D-xylulose kinase defective mutant, a high arabinase production is observed (Witteveen et al. 1989; de Vries et al. 1994). Whether AraR directly interacts with the inducer resulting in its activation or whether the presence of L-arabitol induces post-translational modifications resulting in AraR activation is unknown. As mentioned above, AraR is highly similar in sequence to $\mathrm{X} \operatorname{lnR}$, the transcriptional activator of xylanolytic genes. The exact activation mechanism for $\mathrm{X} \operatorname{lnR}$ is unknown, but phosphate-affinity SDS-PAGE analysis of $\mathrm{X} \ln \mathrm{R}$ in A. oryzae has shown that the C-terminal half of XlnR is highly phosphorylated when D-xylose is present, indicating that phosphorylation controls $\mathrm{X} \operatorname{lnR}$ activity (Noguchi et al. 2011). Which residues in the C-terminus are phosphorylated and whether the phosphorylation is important for XlnR activation is unknown. Whether the AraR phosphorylation status also differs between inducing and non-inducing conditions awaits further studies.

Acknowledgements We thank Jaap Visser for helpful discussions and Tim van Leeuwe and Kevin Groen for their help in strain constructions. Malte Deseke stay in Leiden was supported by ERASMUS scholarship.

\section{Compliance with ethical standards}

Conflict of interest The authors declare that they have no conflict of interest.

Ethical approval This article does not contain any studies with human participants or animals performed by any of the authors.

Open Access This article is distributed under the terms of the Creative Commons Attribution 4.0 International License (http:// creativecommons.org/licenses/by/4.0/), which permits unrestricted use, distribution, and reproduction in any medium, provided you give appropriate credit to the original author(s) and the source, provide a link to the Creative Commons license, and indicate if changes were made.

\section{References}

Alazi E, Niu J, Kowalczyk JE, Peng M, Aguilar Pontes MV, van Kan JAL, Visser J, de Vries RP, Ram AFJ (2016) The transcriptional activator $\mathrm{GaaR}$ of Aspergillus niger is required for release and utilization of Dgalacturonic acid from pectin. FEBS Lett 590:1804-1815

Arentshorst M, Ram AFJ, Meyer V (2012) Using non-homologous endjoining-deficient strains for functional gene analyses in filamentous fungi. Methods in Mol Biol 835:133-150

Arentshorst M, Niu J, Ram AFJ (2015a) Efficient generation of Aspergillus niger knock out strains by combining NHEJ mutants and a split marker approach. In: van den Berg MA, Maruthachalam K (eds) Genetic transformation systems in fungi, vol 1. Springer International Publishing, Cham, pp 263-272

Arentshorst M, Ellen L Lagendijk EL, Ram AFJ (2015b) A new vector for efficient gene targeting to the pyrG locus in Aspergillus niger. Fung Biol Biotech 2:2

Battaglia E, Visser L, Nijssen A, van Veluw GJ, Wösten HA, de Vries RP (2011) Analysis of regulation of pentose utilisation in Aspergillus niger reveals evolutionary adaptations in Eurotiales. Stud Mycol 69: 31-38. https://doi.org/10.3114/sim.2011.69.03 
Battaglia E, Zhou M, de Vries RP (2014) The transcriptional activators AraR and $\mathrm{X} \ln \mathrm{R}$ from Aspergillus niger regulate expression of pentose catabolic and pentose phosphate pathway genes. Res Microbiol 165:531540. https://doi.org/10.1016/j.resmic.2014.07.013

Bos CJ, Debets AJ, Swart K, Huybers A, Kobus G, Slakhorst SM (1988) Genetic analysis and the construction of master strains for assignment of genes to six linkage groups in Aspergillus niger. Curr Genet 14:437-443

Damveld RA, Franken A, Arentshorst M, Punt PJ, Klis FM, van den Hondel CA, Ram AF (2008) A novel screening method for cell wall mutants in Aspergillus niger identifies UDP-galactopyranose mutase as an important protein in fungal cell wall biosynthesis. Genetics 178:873-881. doi: 101534/genetics107073148

de Groot MJ, van de Vondervoort PJ, de Vries RP, vanKuyk PA, Ruijter GJ, Visser J (2003) Isolation and characterization of two specific regulatory Aspergillus niger mutants shows antagonistic regulation of arabinan and xylan metabolism. Microbiology 149:1183-1191

de Groot M, van den Dool C, Wösten HB, Levisson M, vanKuyk PA, Ruijter GJG, de Vries RP (2007) Regulation of pentose catabolic pathway genes of Aspergillus niger. Food Technol Biotechnol 45:134-138

de Ruijter GJ, Vanhanen SA, Gielkens MM, van de Vondervoort PJ, Visser J (1997) Isolation of Aspergillus niger creA mutants and effects of the mutations on expression of arabinases and Larabinose catabolic enzymes. Microbiology 143:2991-2998

de Vries RP, Visser J (2001) Aspergillus enzymes involved in degradation of plant cell wall polysaccharides. Microbiol Mol Biol Rev 65:497-522

de Vries RP, Riley R, Wiebenga A, Aguilar-Osorio G, Amillis S, Uchima CA, Anderluh G, Asadollahi M, Askin M, Barry K, Battaglia E, Bayram Ö, Benocci T, Braus-Stromeyer SA, Caldana C, Cánovas D, Cerqueira GC, Chen F, Chen W, Choi C, Clum A, Dos Santos RA, Damásio AR, Diallinas G, Emri T, Fekete E, Flipphi M, Freyberg S, Gallo A, Gournas C, Habgood R, Hainaut M, Harispe ML, Henrissat B, Hildén KS, Hope R, Hossain A, Karabika E, Karaffa L, Karányi Z, Kraševec N, Kuo A, Kusch H, LaButti K, Lagendijk EL, Lapidus A, Levasseur A, Lindquist E, Lipzen A, Logrieco AF, MacCabe A, Mäkelä MR, Malavazi I, Melin P, Meyer V, Mielnichuk N, Miskei M, Molnár ÁP, Mulé G, Ngan CY, Orejas M, Orosz E, Ouedraogo JP, Overkamp KM, Park HS, Perrone G, Piumi F, Punt PJ, Ram AF, Ramón A, Rauscher S, Record E, RiañoPachón DM, Robert V, Röhrig J, Ruller R, Salamov A, Salih NS, Samson RA, Sándor E, Sanguinetti M, Schütze T, Sepčić K, Shelest E, Sherlock G, Sophianopoulou V, Squina FM, Sun H, Susca A, Todd RB, Tsang A, Unkles SE, van de Wiele N, van Rossen-Uffink D, Oliveira JV, Vesth TC, Visser J, Yu JH, Zhou M, Andersen MR, Archer DB, Baker SE, Benoit I, Brakhage AA, Braus GH, Fischer R, Frisvad JC, Goldman GH, Houbraken J, Oakley B, Pócsi I, Scazzocchio C, Seiboth B, vanKuyk PA, Wortman J, Dyer PS, Grigoriev IV (2017) Comparative genomics reveals high biological diversity and specific adaptations in the industrially and medically important fungal genus Aspergillus. Genome Biol 18: 28. https://doi.org/10.1186/s13059-017-1151-0

Derntl C, Gudynaite-Savitch L, Calixte S, White T, Mach RL, MachAigner AR (2013) Mutation of the xylanase regulator 1 causes a glucose blind hydrolase expressing phenotype in industrially used Trichoderma strains. Biotechnol Biofuels 6:62. https://doi.org/10. 1186/1754-6834-6-62

de Vries RP, Flipphi MJA, Witteveen CFB, Visser J (1994) Characterization of an L-arabitol dehydrogenase mutant. FEMS Microbial Lett 123(1-2):83-90

Flipphi MJA, Visser J, van der Veen P, de Graaff LH (1994) Arabinase gene expression in Aspergillus niger: indications for coordinated regulation. Microbiology 140:2673-2682

Gao L, Li S, Xu Y, Xia C, Xu J, Liu J, Qin Y, Song X, Liu G, Qu Y (2019) Mutation of a conserved alanine residue in transcription factor AraR leads to hyper-production of $\alpha$-L-arabinofuranosidases in Penicillium oxalicum. Biotechnol J e1800643. https://doi.org/10. 1002/biot.201800643
Gruben BS, Mäkelä MR, Kowalczyk JE, Zhou M, Benoit-Gelber I, de Vries RP (2017) Expression-based clustering of CAZyme-encoding genes of Aspergillus niger. BMC Genomics 18:900. https://doi.org/ 10.1186/s12864-017-4164-x

Hasper AA, Trindade LM, van der Veen D, van Ooyen AJ, de Graaff LH (2004) Functional analysis of the transcriptional activator XlnR from Aspergillus niger. Microbiology 150:1367-1375

Ishikawa K, Kunitake E, Kawase T, Atsumi M, Noguchi Y, Ishikawa S, Ogawa M, Koyama Y, Kimura M, Kanamaru K, Kato M, Kobayashi $\mathrm{T}$ (2018) Comparison of the paralogous transcription factors AraR and XlnR in Aspergillus oryzae. Cur Genet 64:1245-1260. https:// doi.org/10.1007/s00294-018-0837-5

Khosravi C, Benocci T, Battaglia E, Benoit I, de Vries RP (2015) Sugar catabolism in Aspergillus and other fungi related to the utilization of plant biomass. Adv Appl Microbiol 90:1-28. https://doi.org/10. 1016/bs.aambs.2014.09.005

Kowalczyk JE, Gruben BS, Battaglia E, Wiebenga A, Majoor E, de Vries RP (2015) Genetic interaction of Aspergillus nidulans GalR, XlnR and AraR in regulating D-galactose and L-arabinose release and catabolism gene expression. PLoS One 10:e143200. https://doi. org/10.1371/journal.pone. 0143200

Kowalczyk JE, Lubbers RJM, Peng M, Battaglia E, Visser J, de Vries RP (2017) Combinatorial control of gene expression in Aspergillus niger grown on sugar beet pectin. Sci Rep 7:12356. https://doi.org/ 10.1038/s41598-017-12362-y

McNeil M, Darvill AG, Fry SC, Albersheim P (1984) Structure and function of the primary cell walls of plants. Annu Rev Biochem 53:625-663

Niu J, Homan TG, Arentshorst M, de Vries RP, Visser J, Ram AF (2015) The interaction of induction and repression mechanisms in the regulation of galacturonic acid-induced genes in Aspergillus niger. Fungal Genet Biol 82:32-42

Niu J, Arentshorst M, Seelinger F, Ram AF, Ouedraogo JP (2016) A set of isogenic auxotrophic strains for constructing multiple gene deletion mutants and parasexual crossings in Aspergillus niger. Arch Microbiol 198:861-868

Niu J, Alazi E, Reid ID, Arentshorst M, Punt PJ, Visser J, Tsang A, Ram AFJ (2017) An evolutionarily conserved transcriptional activatorrepressor module controls expression of genes for D-galacturonic acid utilization in Aspergillus niger. Genetics 205:169-183

Noguchi Y, Tanaka H, Kanamaru K, Kato M, Kobayashi T (2011) Xylose triggers reversible phosphorylation of $\mathrm{X} \ln \mathrm{R}$, the fungal transcriptional activator of xylanolytic and cellulolytic genes in Aspergillus oryzae. Biosci Biotechnol Biochem 75:953-959

Numan MT, Bhosle NB (2006) $\alpha$-L-arabinofuranosidases: the potential applications in biotechnology. J Ind Microbiol Biotechnol 33:247-260

Pel HJ, de Winde JH, Archer DB, Dyer PS, Hofmann G, Schaap PJ, Turner G, de Vries RP, Albang R, Albermann K, Andersen MR, Bendtsen JD, Benen JA, van den Berg M, Breestraat S, Caddick MX, Contreras R, Cornell M, Coutinho PM, Danchin EG, Debets AJ, Dekker P, van Dijck PW, van Dijk A, Dijkhuizen L, Driessen AJ, d'Enfert C, Geysens S, Goosen C, Groot GS, de Groot PW, Guillemette T, Henrissat B, Herweijer M, van den Hombergh JP, van den Hondel CA, van der Heijden RT, van der Kaaij RM, Klis FM, Kools HJ, Kubicek CP, van Kuyk PA, Lauber J, Lu X, van der Maarel MJ, Meulenberg R, Menke H, Mortimer MA, Nielsen J, Oliver SG, Olsthoorn M, Pal K, van Peij NN, Ram AF, Rinas U, Roubos JA, Sagt CM, Schmoll M, Sun J, Ussery D, Varga J, Vervecken W, van de Vondervoort PJ, Wedler H, Wösten HA, Zeng AP, van Ooyen AJ, Visser J, Stam H (2007) Genome sequencing and analysis of the versatile cell factory Aspergillus niger CBS 513.88. Nat Biotechnol 25:221-231

Shallom D, Shoham Y (2003) Microbial hemicellulases. Curr Opin Microbiol 6:219-228

Tefsen B, Lagendijk EL, Park J, Akeroyd M, Schachtschabel D, Winkler $R$, van Die I, Ram AF (2012) Fungal $\alpha$-arabinofuranosidases of glycosyl hydrolase families 51 and 54 show a dual 
arabinofuranosyl- and galactofuranosyl-hydrolyzing activity. Biol Chem 393:767-75. https://doi.org/10.1515/hsz-2012-0134

van der Veen P, Flipphi MJA, Voragen AGJ, Visser J (1993) Induction of extracellular arabinases on monomeric substrates in Aspergillus niger. Arch Microbiol 159:66-71

van der Veen P, Arst HN Jr, Flipphi MJ, Visser J (1994) Extracellular arabinases in Aspergillus nidulans: the effect of different cre mutations on enzyme levels. Arch Microbiol 162:433-440

van Hartingsveldt W, Mattern IE, van Zeijl CM, PH Pouwels PH, CA van den Hondel CAM (1987) Development of a homologous transfor- mation system for Aspergillus niger based on the $p y r G$ gene. Mol Gen Genet 206:71-75

Witteveen CFB, Busink R, van de Vondervoort P, Dijkema C, Swart K, Visser J (1989) L-arabinose and D-xylose catabolism in Aspergillus niger. Microbiology 135:2163-2171

Publisher's note Springer Nature remains neutral with regard to jurisdictional claims in published maps and institutional affiliations. 